\title{
Between contact and internal development: towards a multi-layered explanation for the development of the TMA system in the Creoles of Suriname*
}

This paper proposes a new analysis of the formation of the TMA system of the Surinamese Maroon Creoles based on a wide range of both contemporary and historical sources. The paper first provides a brief synopsis of the socio-historical context in which the Creoles of Suriname emerged and developed, and a broad overview of the TMA systems of those Creoles and of varieties of Gbe. It then discusses four processes that were involved in the emergence of the creole TMA system: substrate influence, internal change from a substrate calque, superstrate influence, and shift of form and category correlated with innovation. The paper then concludes that Creole formation is to be considered as a gradual and multi-layered process (Arends 1993, Bruyn 1995), involving processes of language change that also operate in other so-called 'normal' contact settings (Thomason \& Kaufman 1988).

\section{Introduction}

The tense, mood and aspect system of Creoles has been at the center of much of the debate on Creole genesis. Over the years, different kinds of explanations have been offered for its origins. Bickerton (1984), for instance, appealed to innate linguistic knowledge, the so-called bioprogram, to explain the structure of Creole TMA systems. Lefebvre (1996), and Siegel (1999) in a somewhat different way, on the contrary, argue that the structural makeup of these languages, including their TMA categories, emerged due to substrate influence. Superstratists, instead, argue that the grammar of Creoles can be, in large part, traced to the European language involved in their formation (Chaudenson 1992) while the first languages of the slaves would have only played a limited role in their emergence (DeGraff 2002). Finally, in recent years evidence has also been brought forward to demonstrate that at least some of the elements in Creole TMA systems emerged due to internal change (Detgers 2000, van den Berg 2001, Kriegel, Michaelis \& Pfänder 2004, Fattier 2003). Together the findings from these different approaches clearly argue against a mono-causal explanation for the formation of Creole grammars and Creole TMA systems in particular. However, little of the current research investigates how the different sources conspired to give rise to specific contemporary Creole grammars.

\footnotetext{
* The research on the contemporary Creole and Gbe varieties was funded by NSF grant \# SBR 930635 and NSF grant BCS-0113826. We would like to thank the numerous informants in Benin and Suriname/French Guiana who generously provided information on their native languages.
} 
The aim of the present paper is to demonstrate the multi-layered nature of the process of Creole formation. Investigating in detail the processes and sources that were involved in the emergence and development of the TMA system of the Creoles of Suriname, we show that the contemporary TMA system of the Creoles of Suriname emerged due to contact-induced language change, language internal change, and universal processes of second language acquisition.

Our analysis draws on a range of data sources. Natural and elicited data were collected from relatively conservative varieties of four contemporary Creoles of Suriname (Sranan Tongo, Ndyuka, Paamka, Saamaka) and their main substrate, varieties of Gbe. The Gbe data were collected from varieties belonging to the main subclusters of the Gbe continuum (Capo 1988). The elicitations for all these varieties employed a modified version of Dahl's (1985) questionnaire (for details, see Migge to appear). The historical data for Sranan Tongo and Saamaka come from the following sources: the Court Records from 1607 until 1667 (in van den Berg 2000); Herlein 1718, van Dyk 1765, Nepveu 1770 (in Arends \& Perl 1995); the Saramaccan Peace Treaty in Sranan (1762) (van den Berg \& Arends 2004); Schumann's dictionary of Sranan (1783) (Kramp 1983); a Saramaccan dictionary \& grammatical sketch by Riemer (1779) (in Arends \& Perl 1995) which was based on Schumann's (1778) Saramaccan dictionary published in Schuchardt (1914); the translation of the story of the Apostles by Wietz 1805 (in Schuchardt 1914); the Neger-Engelsh - Nederlands Woordenboek from Focke 1855 (Online at http://www.sil.org/americas/suriname/Focke/National/FockeNLDict.html).

The paper is organized as follows: Part One presents a brief synopsis of the sociohistorical context in which the Creoles of Suriname emerged and developed. Part Two provides a broad overview of the TMA systems of the Creoles of Suriname, their main substrate input, varieties of Gbe, and English. Part Three discusses the different sources and processes that were involved in the emergence of the TMA system by investigating in detail specific areas of the TMA system. The last part summarizes the findings and discusses their implications for theories of Creole genesis.

\section{The historical context}

\section{1. Overview of the contact settings}


Analyses of the early history of Suriname (Arends 1995, Migge 2002) suggest that it can be subdivided into three distinct contact settings. The first contact setting (16511679) spans the founding of the English colony in 1651 and its handover to the Dutch in 1667 following the Anglo-Dutch war. This period was characterized by relatively high ratios of Europeans to Africans (1:2 to 1:3) and old slaves to new slaves (less than 1:2). Initially, the Europeans were mainly speakers of English. In 1670s they were replaced by speakers of different European languages such as Dutch, Swedish, German, French. Starting in 1665 Jewish migrants from Cayenne and various Sephardic communities in Europe (Arends 1999) and/or from Brazil (Goodman 1987) introduced varieties of Portuguese and Spanish. The Africans were native speakers of Gbe, Kikongo and Akan (Arends 1995). Some of the early Europeans and slaves would have also been speakers of (non-native) varieties of English and Englishlexified Creoles current in other British possessions. In this early period, the European indentured laborers, owners of homesteads and African slaves lived and worked in close contact with each other (Rens 1953).

This situation dramatically changed with the onset of the plantation economy (1680-1695). The massive importation of African slaves led to a change in the makeup of the population. It now consisted primarily of slaves from Africa speaking Gbe and Kikongo while the Europeans and the early slaves were clearly in the minority. The ratio of Europeans to Africans dropped from 1:2/3 (1679) to 1:12 and during the 1680 s the ratio of old to 'new' slaves decreased from nearly 1:2 to nearly 1:7 (Arends 1995).

The plantation setting involved a much greater number of manual laborers per agricultural unit and its population was subdivided into three social groups with different positions in the social hierarchy of the plantation. The European planter family and their European assistants were at the top of that social hierarchy, the new slaves were at the bottom, and the early slaves occupied an intermediate position. The new slaves were the largest group and were responsible for the planting, harvesting, transporting, etc. of the plantation's main cash crop. The elite slaves made up about $15 \%$ of the population and performed more skilled jobs. The Europeans consisted of one or two people and organized and supervised the work.

Due to this stratification the members of each social group now primarily interacted among themselves and much less with members from other social groups. The latter interactions took on a hierarchical nature and became restricted to relatively 
non-complex work-related matters while the former had a less hierarchical character and also involved a wide variety of social functions. Moreover, while the early slaves and the Europeans had and shared common social and linguistic conventions established during the previous period, the new slaves did not. They had to forge them based on their native conventions and those they encountered on the plantations. Access to the latter must have been quite restricted though due to absence of close contact with the other two social groups.

Between 1695-1720 the importation of slaves continued at a somewhat lower rate and the new arrivals were no longer the numerically dominant group. The ratios of Europeans to Africans continued to decrease and the ratios of old to new slaves increased continually. At this time, about $70 \%$ of all the slaves brought to Suriname were speakers of Gbe and only less than $20 \%$ were speakers of Kikongo varieties. During this period the varieties of Gbe and, more importantly, varieties of the plantation Creole that had emerged in the second period must have gained considerable prominence.

This brief discussion suggests that 'the creole' must have crystallized around the end of the $17^{\text {th }}$ and the early $18^{\text {th }}$ century during the transition from the homestead to the plantation economy. The linguistic inputs to the initial formation of the plantation Creole were (reduced) L2 varieties of English and to a lesser extent of Portuguese, and the L1s spoken by the slaves, mainly varieties of Gbe and Kikongo. The main process of contact was interference through shift. Essentially, speakers of Gbe and Kikongo varieties acquired reduced English structures and partially or completely reinterpreted them according to linguistic principle from their linguistic background, including their native languages, other languages they were familiar with and universal strategies of contact. The varieties that emerged during the transition period became the main means of communication and served as targets of acquisition for new arrivals during the third setting.

Following its initial emergence, the plantation varieties came into contact with a range of other languages that would have been spoken by the slaves brought to Suriname in the period between 1720 and 1863, when the slave trade officially ended. They included Kwa languages spoken in modern day Ghana, e.g. Gã, Twi, Ashante, but also languages found in the region ranging from modern day Ivory Coast to Sierra Leone (Arends 1995). After the end of the slave trade and particularly following the abolition of slavery, the impact of the African languages slowly diminished. 
Dutch hardly played an important role in $17^{\text {th }}$ and $18^{\text {th }}$ century Suriname (de Kleine 2002). It was only during the $18^{\text {th }}$ century that Dutch started to be more widely diffused in the colony. The main agents in this process were descendants of mixed Afro-Surinamese-European unions who were quite wealthy, well-educated and occupied important social positions. They adopted Dutch as their main language to distinguish themselves from the slave population (de Kleine 2002: 211). However, Dutch existed in close contact with Sranan (Tongo), the coastal Creole, and was much influenced by it, see for example the Dutch used in the translations of Van Dyk's manual (de Kleine $2002: 211$ ). Sranan was the main interactional language in both Paramaribo and on the plantations and was learned as a first language by most Surinamese. Dutch was rapidly gaining in importance during the nineteenth century. According to de Kleine (2002), well-situated families increasingly sent their children to Holland for their education and a growing number of non-white intellectuals and members of the middle class adopted Dutch as their main means of expression, teaching it also as a first language to their children. The vast majority of AfroSurinamese, however, remained dominant in Sranan and had little opportunity to learn Dutch until 1876 when it was made the obligatory medium of instruction in Surinamese schools. As a result, a range of L2 varieties of Dutch that show varying degrees of influence from Sranan have been emerging and Sranan has been subject to increasing influence from Dutch. The majority of the Surinamese population, and especially the Maroons, however, would have had little or no access to Dutch. The differences between the Bakra and Nengre varieties of Sranan posited by Schumann (1778) and Riemer (1779) may be largely due to differential Dutch influence.

\section{2 Marronage}

The Surinamese context is unique in that it has given rise to a family of Creole languages. To date seven different Creoles survive. Sranan Tongo (literally: Suriname Tongue) is the direct continuation of the early plantation varieties since "historically [it is] the language of the slaves inhabiting the plantation zone of the coast and the lower reaches of the major rivers." (Smith 1987: 3). Today, it is the mother tongue of the Afro-Surinamese population living in the coastal region and functions as a lingua franca in multiethnic Suriname. The other Creoles Aluku, Ndyuka, Pamaka, Kwinti, Saamaka and Matawai split off from the plantation Creole at different times during 
the 18th century as a result of marronage by the founders of the communities who speak these languages.

Marronage is a form of resistance to slavery and can be defined as desertion of the plantation with the aim of living out of the reach of the planters and the institution of slavery (Hoogbergen 1983: 75). The most common form was step-by-step marronage. First, individual slaves migrated to the secondary forest around the plantations, established a shelter and tried to make a living off the crops growing on the old fields (kapuweri) and from the things they obtained from the slaves from nearby plantations (Hoogbergen 1983: 78). After a while, several such runaways joined forces and formed a small group. They continued to depend on the plantations but also generally established fields and semi-permanent houses further away from the plantations. Once the planting grounds supplied sufficient food for the whole group, the hiders permanently settled close to their fields and established fully-fledged communities. A primary activity consisted of attracting new members, particularly women and children, through either relocating family members or abducting women from the plantations (Hoogbergen 1983: 80).

This scenario suggests that the early slaves spoke the language varieties practiced on the plantations. Their varieties also would not have quickly diverged significantly from the plantation varieties because of continued contact between slaves and maroons. However, since runaways were generally African rather than locally born (van den Putte 2005), it is quite possible that, at least initially, the African L1s would have had a more significant influence on the maroon varieties.

Since the end of the $18^{\text {th }}$ century, Maroons have been in contact with the Amerindians living along the Maroni River and in the forest, like the Trio in Suriname, or the Wayana in French Guiana. ${ }^{1}$ They developed exchange partnerships that gave rise to the creation of contact languages such as the Ndyuka-Trio Pidgin (see Huttar \& Velanti 1997, Carlin 2002: 25). The Eastern Maroon Creole varieties (EMC), namely Ndyuka, Pamaka and Aluku, also borrowed much of their vocabulary for fauna, flora and traditional techniques of hunting and fishing from Carib languages.

\footnotetext{
${ }^{1}$ The Aluku, for example, made contact with the Wayana in the 1790's, in the Tumuc-Humac montains (Dupuis 2005).
} 


\section{Broad Overview of the TMA system in the Creoles of Suriname and in Gbe}

Overviews of the TMA system in the Creoles of Suriname (see Winford \& Migge to appear; Migge to appear) show that there are a number of significant similarities between these four Creoles in the area of TMA. First, TMA distinctions are generally expressed by preverbal forms with the exception of the Completive Perfect marker kaba which occurs post-VP in all varieties. Second, for the most part, the Creoles share the same TMA categories and generally also employ the same forms to express them; differences are mostly phonological in nature. More important differences are found in two areas. Imperfective aspect is expressed by the element $t a$ in Saamaka which is unrelated to $e$ in Sranan and the EMC varieties. In the case of the Potential category, the element $s a$ has a different distribution in each variety and competes with other forms in several of the Creoles.

Studies of TMA in Gbe (Lefebvre 1996, 1998, Lefebvre \& Brousseau 2002; Migge \& Winford to appear; Migge to appear) also reveal significant similarities among the Gbe varieties. When comparing the Gbe and the Surinamese TMA system, several similarities and differences emerge. In relation to the overall structure of the system, these studies demonstrate that the Gbe varieties encode a temporal opposition between Future and non-future while the Creoles make a distinction between Future and Past. In the area of aspect, the Gbe varieties have distinct Habitual and Progressive categories while the Creoles of Suriname have one Imperfective category that covers habitual, progressive and continuous meanings. Finally, several of the Gbe varieties have a Prospective aspect category but the Creoles of Suriname do not. In the area of modality, the most important difference is that the Gbe varieties have a Subjunctive category while the Creoles of Suriname do not. This broad comparison then suggests that the Gbe varieties clearly contributed to the emergence of the Surinamese TMA system. However, other sources and processes must have also played an important role since the Surinamese TMA systems are clearly not exact copies of the Gbe TMA systems.

Based on the sociohistorical context, English would have been the most likely source for such an influence. However, even a brief comparison of TMA categories in English and in the Creoles of Suriname reveals important differences. English distinguishes between three temporal categories, Present, Past and Future. While Future is expressed by a preverbal form, the Past is obligatorily expressed on the verb 
by means of a suffix or other vocalic changes in verb form. The Present is mostly unmarked. In the area of Aspect, English distinguishes between progressive and continuous aspect conveyed by the to be $+\mathrm{V}-$ ing construction and a Present Perfect Aspect expressed by auxiliary have + past participle form that denotes an event or state begun in the past with relevance for the present. Modality is conveyed by preverbal forms in both English and the Creoles of Suriname but the forms and the meanings they express are partially different. For instance, English does not distinguish between learned ability and physical ability. There is also not a Potential category in English. Ability and Root Possibility are expressed by the element can while permission and epistemic possibility are expressed by may. Closer similarities are found in the areas of Necessity and Desire. The forms used to express them in most of the Creoles ( $m u(s u)$ and wani resepectively) are clearly derived from the English forms and they also have at least partially similar distributions.

\section{The origin of the TMA system of the Creoles of Suriname: A multi-causal approach}

When comparing the contemporary TMA systems of the Creoles of Suriname with those of their input varieties (Gbe and English), and with available data on earlier stages of Sranan and Saamaka, it is possible to draw conclusions about the processes that played a role in the formation and development of the TMA system of the Surinamese Creoles. Below we discuss four such processes: 1. substrate influence, 2. internal change from a substrate calque, 3. superstrate influence and 4. shift of form and category with innovation. The discussion suggests that creolization was a gradual rather than an abrupt process (Arends 1993). However, it was clearly not a homogeneous or linear process but seems to have been multi-layered; different kinds of changes took place at different moments in the history of these Creoles.

\subsection{Substrate influence: perfective category}

The Perfective Aspect category appears to have emerged in the Creoles of Suriname due to substrate influence (Winford \& Migge to appear). Semantically, this category presents a situation as an unanalyzed whole without regard to its internal structure (Comrie 1976: 16). Its exact meanings differ depending on the context and the predicates involved (Winford 2000b). In both the Surinamese Creoles and in Gbe it is 
realized by the unmarked verb form and employed to express a similar range of meanings. When the discourse context establishes speech time as the point of reference, the default interpretation of the unmarked verb conveys 'present' time reference with stative verbs ${ }^{2}(1)$ and property items (2).
(1) Aja
a. Nsuvi lo jefi nyonuvi lo.
boy DET know girl DET
Pamaka b. A boy sabi a meyse.
DET boy know DET girl

'The boy knows the girl.'
(2) Gen
a. Esi a fa.
water DET cold
Saamaka b. Di wata aki koto.
DET water here cold
'The/this water is cold.'

With activity verbs, it generally has a 'simple past' time reference (3).
(3) Xwela

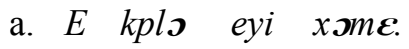
he clean his room
Pamaka b. A kiin/seeka en kamba.
he clean/arrange his room
'He cleaned his room.'

Gbe differs from the Creoles in that the unmarked stative verb may also have past time reference. In the Creoles the verb is generally preceded by the past time marker. The unmarked verb is also used to convey the sense of current relevance and successivness of actions in the past in both languages.

\footnotetext{
2 'Stative verbs' is used here to refer to the verbs that may denote a 'state (...) characterized by absence of change, of discontinuity; all phases of the static situations are the same' (Desclés 1989: 172). It is a semantic property that does not correspond to any morphological class of verbs in the Maroon Creoles. The fact that they can be combined with the imperfective marker suggests that they are actually process-denoting verbs (cf. Winford 1997, Migge 2000 for property items).
} 
The Perfective aspect category has also been remarkably stable over time in the Creoles. In the early texts it is also expressed by the unmarked verb and presents a situation as an unanalyzed whole (4).

(4)

$$
\begin{aligned}
& \text { (vD) mi kom fo takki joe gran odi van wan zomma. } \\
& \text { I come to talk you big regards of one people } \\
& \text { 'I came to give you someone's regards.' }
\end{aligned}
$$

(Arends \& Perl 1995 : 147)

State-denoting verbs and property items (5) usually have a present time reference while activity verbs receive a past-time reference (6).

$$
\begin{array}{ll}
\text { (Sch.) mi membre hem. } & \\
\text { I think him } \\
\text { 'I think of him.' } \\
\text { (Kramp 1983 : 189) }
\end{array}
$$

(6) (SPT) A poti alle dissi santi deja na inni gi dem he put all these thing here LOC inside give them 'He wrote all these things down for them.'

(Arends \& van den Berg 2004 : 1)

Stative verbs with past time reference are preceded by ben (7):

$$
\begin{array}{ll}
\text { (vD) Mino ben zabi. } \\
\text { I-NEG PAST know } \\
\text { 'I didn't know that.' }
\end{array}
$$

(Arends \& Perl 1995 : 136)

Moreover, in the early texts, the unmarked verb form is also already used to express successivness (8).

(8) (vD) Mastra Aurora de go na koekeroe kaba voete missi, master Aurora IPFV go LOC kitchen and foot miss 
$\begin{array}{lllll}a & \text { brokke } & d a & \text { pletti metti fadom } & \text { na dotti. } \\ \text { she break } & \text { DET plate meet fall_down LOC floor }\end{array}$

'Overseer, Aurora was going to the kitchen, but she stumbled, broke the plate and the meet fell down on the floor.'

(Arends \& Perl 1995 : 181)

Together, these data strongly suggest that the Perfect aspect category emerged at the time of Creole formation and that it arose as the result of substrate influence. 
Imperfective is conveyed by $e$ in Sranan and Eastern Maroon varieties, and by $t a$ in Saamaka (9). $E$ derives from the locational copula $d e$ and $t a$ derives from the verb tan 'to stay'.

[A: What is your brother doing right now?]

(9) Pamaka a. B: A e seeka en osu. he IPFV clear his room

Saamaka b. B: A ta seeke hen kamba. he IPFV arrange his room 'He is cleaning his room.'

In the Gbe varieties different strategies exist to mark progressive aspect. In most varieties of Gbe the verb 'be-at' selects a nominalized VP, either a reduplicated verb (VV 11) or XP-V construction (10a) marked by a particle (Fabb 1992). In Gen and Xwela, as in the Creoles (9), the verbs 'be-at' (10a, b) and 'stay' (10c) respectively, precede the unreduplicated/inverted verb.
(10) Waci

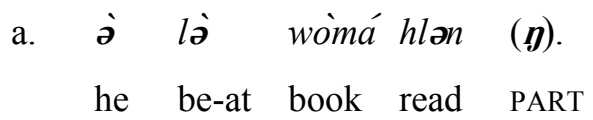
'He is reading a book.'
Gen b. É lé wlon nú.
he be-at write thing
'He is writing something.'
Xwela c. E no xle wema.
he stay read book
'He is reading a book.'
In both languages, the progressive construction expresses a sense of an event or activity in progress. However, with property items and certain psychological state verbs, an inchoative or 'in-process' meaning is conveyed (11-12). In combination with motion verbs, the progressive construction expresses a future sense. 
(11) Gun
a. Sìn ló tò fífà. (Aboh, pc 2004)
water DET PROG Red-cold

'The water is getting cold/hot.'
Pamaka b. Den dey ya den manyan e lepi.
DET day here DET mango IPFV ripe.

'These days the mangos are ripening.'

(12) Waci

a. Me le nu nyá-y le sukulu fifiia.

I PROG thing know-PART LOC school nownow

'I am now understanding lessons at school.'

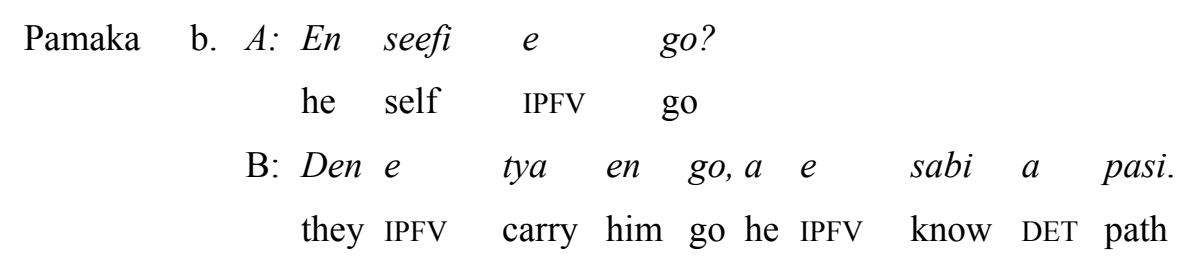
'A: Does he go [to the toilet] himself? B: They bring him, he is getting to know the way.' (PM 11)

There is also another similarity: The marker $e$ in the Creoles is derived from the locational verb de (Arends 1986) and the initial element in the progressive construction in Gbe is also a locational verb (Jondoh 1980, Fabb 1992).

The evidence suggests that the emergence of $d e$ as a locational verb in the Early Plantation varieties triggered its extension to the marking of progressive aspect. The model for this extension was the fact that the locational verb in a number of Gbe languages is also involved in the progressive construction (Winford \& Migge to appear).

The Creole progressive markers $e$ and $t a$ differ from their Gbe counterparts in that they are used to express habitual (13) and generic meanings. In Gbe these meanings are typically conveyed by a separate habitual marker in Gbe (14).

[What does you brother do after dinner?]
(13) Ndyuka
a. A e leysi wan buku.
he IPFV read one book
'He (usually) reads a book.' 
(14) Maxi

a. E no xa wema.

he PROG read letter

'He usually reads books.'

The progressive markers may though appear in contexts that have a habitual reading, usually due to the presence of adverbs that convey habituality (15).

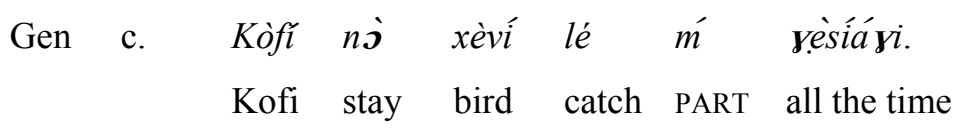

'Kofi is always catching birds.' (Jondoh 1980:39)

In the Early Texts de/tan clearly have a progressive meaning (16), and a continuous meaning (17). Habitual meaning is not clearly found, but can be inferred from the context (18).

$O$ goedoe gado masra, koudemaas de foen mi misjie

o good God master, Koudemaas IPFV rape my woman

'O my God, Koudemas is raping my woman.'

(van den Berg 2000 : 94)

(17) (vD)

$$
\begin{aligned}
& \text { mi blibi no wan zomma de go lange da boote. } \\
& \text { I think NEG one someone IPFV go with DET boat } \\
& \text { 'I don't think anybody's going with that boat.' }
\end{aligned}
$$

(Arends \& Perl 1995 : 214)

[the manager is talking about 'the good life' of the housemaids] :

Den kiesi zwiti jam jam kabaden de slibi lange mi they catch sweet food and they IPFV sleep with me 'They get nice food and they sleep with me.'

(Arends \& Perl 1995 : 186)

The generic meaning of the imperfective construction is not clearly attested in the early texts. Van Dyk presents generic constructions without de (19) whereas Focke's dictionary includes many proverbs that employ $d e$ as a generic marker (20). The data 
do not really allow us to conclude that the meaning of $d e$ (gradually) broadened during this period to include the sense of 'generic'.

Mastra da worke wawan no myki pranasie master DET work alone NEG make plantation 'It's not just the work that makes a good plantation, master.' (Arends \& Perl 1995 : 208)

Bérgi-nánga bérgi no de míti makándra,
mountain-with mountain NEG IPFV meet together
ma sóema nánga sóema sa míti
but people with people FUT meet

'Mountains do not meet, but people can meet each other.'

(Focke 1855, see at ,Bergi')

Overall the evidence suggests that the emergence of $d e$ as a locational verb in the Early Plantation varieties, based on substrate models (Migge 2002), was the trigger for its extension to the marking of progressive aspect. However, it seems likely that in this case substrate influence was reinforced by universal tendencies because the grammaticalization from the locative verb to progressive markers is a well-attested process cross-linguistically (see Bybee \& alii 1994; Heine \& Kuteva 2002). The meaning of $d e$ extended from a specific meaning, progressive, to a more general value of 'unbounded situations' that allows nowadays a generic and habitual interpretation. The phonological reduction from early $d e$ to present day $e$ completed this process of internal language change that originated with a calque on a substrate structure.

\subsection{Superstrate influence: relative past time category}

The marker of relative past time reference in all the Creoles derives from the English past participle been, ben in Sranan, be in the EM varieties and $b i$ in Saamaka (21). In its prototypical function, it "locate[s] some situation as occurring prior to the time reference point under focus in the discourse" (Winford 2000b: 400) which is either the moment of speaking (21) or another event (22). 
(21)

$$
\begin{array}{llllll}
\text { Saamaka } & A & b i & \text { wasi } & \text { wosu eside. } \\
& \text { he } & \text { PAST } & \text { wash house yesterday }
\end{array}
$$

'He cleaned his house.'

[regarding a window that is now closed:

You OPEN the window (and closed it again?)]

$\begin{array}{ll}\text { (22) Pamaka } & \text { Iya } m i \text { be opo en. } \\ & \text { yes I PAST open it } \\ & \text { 'Yes I opened it.' }\end{array}$

$B e n / b e / b i$ is optional when past time reference is indicated by other means. In such contexts it usually indicates a past before past (23) or backgrounded information (see for example Winford 2000b: 401)

$\begin{array}{ll}\text { (23) Pamaka } & \text { Iya, mi (be) si en. } \\ & \text { Yes I PAST see him } \\ & \text { 'Yes, I met him.' }\end{array}$

When ben/be/bi precedes verbs expressing requests and invitations, it may also convey hypothetical meaning (24) to mitigate the effect of a face threat.

$$
\begin{array}{lllllll}
\text { Pamaka } & \text { Mi be wani kon luku } i \quad \text { moo lati. } \\
\text { I PAST want come look you more late } \\
\text { 'I wanted to come visit you later on.' }
\end{array}
$$

In conditional clauses it also expresses counterfactuality in the if-clause, and, in combination with $s a$ or $o$, an unrealized event in the consequent clause (25).

(25) Pamaka

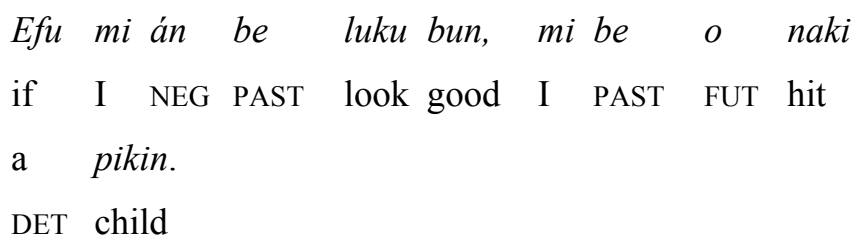

'If I had not been careful, I would have hit the child.' 
Gbe does not have a relative past time marker. Verbs that have past time reference usually appear in the unmarked verb form and the past time reference is established through the discourse context or by adverbial form. All varieties of Gbe, however, employ a post-verbally occurring adverbial form meaning 'before' to indicate a past before past state or activity (26a) or simply a state that no longer exists (26b). This form is still subject to further investigation.

[regarding a window that is now closed:

You OPEN the window (and closed it again?)]

(26) $\quad$ Aja



'No, I did not open it.'

$S a(n)$ in Gbe also regularly occurs in conditional clauses to express counterfactuality in the if-clause (27).

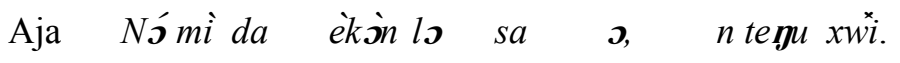
If we throw fist DET before PART I can beat-him

'If we'd hit each other, I could have beat him.'

These data then suggest that although there appears to be some overlap between the Creole relative past category and past marking strategies in Gbe, the Creole category does not seem to have been directly modeled on Gbe strategies.

In the early texts, past time reference was from the beginning marked by ben/bin in Early Sranan and by $b i$ in Early Saamaka. It conveyed two principal meanings:

1. a situation occurring prior to the moment of speech :

(vD) Tide da jarri den ben myki mi Mama.
today COP year they PAST make my mother
'Today's my mother's birthday.'


2. a situation occurring prior to a past event :

(29) (vD) Hoe tem joe kom Disi mino ben de. Q. time you come REL I-NEG PAST be 'What time did you come...when I wasn't home?' (Arends \& Perl 1995 : 136)

Ben is generally used to indicate past time reference with state-denoting verbs (see 7). In hypothetical clauses, ben can appear in the protasis (if-clause) or in the main clause, and when it is combined with $s a$, the construction conveys a meaning of conterfactuality :

(30) (Schu) effi mi no ben takkigi ju, ju no ben sa sabi if I NEG PAST talk to you you NEG PAST FUT know 'If I had not told you, you wouldn't have known.'

(Kramp 1983: 60)

Schumann attested the hypothetical meaning of $b i$ in Saamaka even in clauses not introduced by if and explains that $b i$ is a 'conjuntivi et optativi' marker (31) :

(31) (Sch-Sa) $a \quad$ bi bun, effi a bi wakka.

it PAST good if he PAST walk

'It would have been good if he had gone.'

(Schuchardt $1914: 53$ )

Another function of ben/bin in Early Sranan is to mitigate a demand :

(32) (vD) Mi ben hangeri fo takke lange joe.

I PAST hungry for talk with you

'I would have liked to talk to you.'

(Arends \& Perl 1995: 132) 
The early texts show that the past category and its secondary meanings were already well established at the end of the 18th century. Etymologically, the marker clearly derives from the English past participle been and functionally, it matches up most closely with the English past tense. As in the Creoles, the English past tense does not only convey a temporal meaning, but also conterfactuality, and is used in polite requests (Comrie 1985).

\subsection{Shift of form and category, and innovation}

In the contemporary Surinamese Creoles later time reference (33), intention (34) and prediction (35) is conveyed by $o$ while uncertain future is generally expressed using the Potential mood-marking element $s a(36)$ or the future marker in combination with an adverb expressing uncertainty (37).

(33) Ndyuka

a. A o kon ya tamaa.

he FUT come here tomorrow

'He'll come tomorrow.'

(34) Ndyuka a. Te mi (o) kon gaandi, mi o bay wan gaan when I FUT come old I FUT buy a big osu.

house

'When I am old, I'll buy a big house.'

(35) Ndyuka

a. Ef(u) $i$ poti wan siton a ini a pikin tasi, if you put a stone LOC in DET little bag a o piiti en.

it FUT rip it

'If you put a stone in this bag, it'll rip.'

(36) Ndyuka
J. sa go a Faansi taa wiki.
J. may go LOC France other week 
'J. may go to France next week/it is possible that J. will go to

France next week.'

(37) Ndyuka

b. Kande, J. o/sa go a Faansi taa wiki.

maybe J. FUT go LOC France other week

'J. may go to France next week/ it is possible that J. will go to

France next week.'

The same distribution is also found in several of the Gbe varieties (Fon varieties, Aja, Phla-Phera) where lá, ná or $a ́$ is used to mark predictive future and the potential modality markers such as sixu (Maxi) and $t \boldsymbol{\varepsilon} n$ (Xwla) convey uncertain future (Migge to appear). In other varieties, such as Gen and Ewegbe varieties, lá, á seem to have strong overtones of potentiality. Essegbey (2004) argues that $a$ in Anlo is a potential rather than a future marker because it conveys epistemic possibility by itself (38a) and contributes an uncertainty or potential meaning when it is combined with the abilityexpressing marker (38b).

(38) Anlo

a. (Mewohĩ) John $\hat{a}-n \boldsymbol{D}$ afeme fifia. maybe John POT-be_located home now 'John may be at home now (= It's possible that John is at home now).'

b. Tsi $\hat{a}$-te $\boldsymbol{\eta} u \quad \dot{a}-d z a \quad l e \quad z \tilde{a}$ sia me.

water POT-be_able POT-fall LOC night this in 'It may rain tonight (= It's possible it will rain tonight).'

In the early texts, by contrast, future tense is marked by several markers: $s a$, de go in van Dyk, and go / de go in Schumann. Za/zal, which seems to have a Dutch origin $^{3}$, and generally conveys a sense of 'later time reference':

$$
\begin{array}{ccccc}
\text { (vD) mi } & \text { za } & \text { myki } d a & \text { merki morre bikki } \\
\text { I } & \text { FUT make DET mark more big }
\end{array}
$$

\footnotetext{
${ }^{3}$ An English origin does not seem plausible because in the second part of the $18^{\text {th }}$ century shall is becoming scarce (Groussier, p.c) and finally disappeared in many of its primary uses. The 'shall-willwill' rule, created in 1653 , certainly reached more the upper classes of the society than the candidates for colonisation.
} 
'I'll make (the mark) bigger.'

(Arends \& Perl 1995 : 176)

(40) (Sch.) na abra dina mi sa kom.

LOC over diner I FUT come

'I will come in the afternoon.'

(Kramp $1983: 84$ )

Uncertain future is expressed by the meaning of the adverb zomtem ${ }^{4}$ 'perhaps' combined with the marker $s a(41)$.

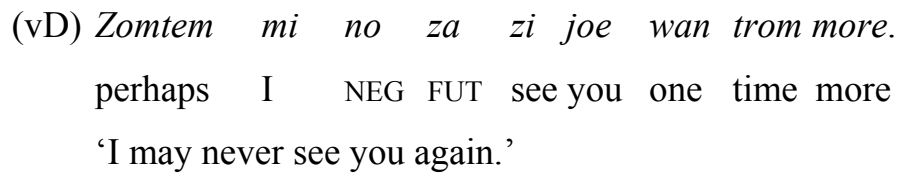

However, present-day $o$ more likely developed from the constructions go $V$ and de go $V$ than from $s a$. Apart from similarities in form, grammaticalization of a 'movement towards a goal construction' (I'm going to...) to a future construction is a well-attested path of development (Bybee \& alii 1994, Heine \& Kuteva 2002).

While van Dyk includes only one example of the go $V$ future construction and four of the de go future construction, they are already much more frequently attested in Schumann. In the entry for go he also notes: « Auch wird go sehr haüfig als nota futuri anstatt $s a$ gebracht » (Kramp $1983: 110)$.

(42) (Sch)a de go passaabra he IPFV go pass over 'It will overflow.'

(Kramp $1983: 45)$

\footnotetext{
${ }^{4}$ Zomtem disappeared in the MCs and Sranan. It was reimplaced by kande 'perhaps' which conveys a meaning of 'epistemic possibility' when combined with $o$ or $s a$. This form is not attested until the second part of the $19^{\text {th }}$ century (see Focke's dictionary 1855).
} 
In Schumann the go - de go constructions also already appear with a greater range of subjects. The fact that they occur with [-animated; - control] subjects, in particular, suggests that go/de go were fully grammaticalized as future markers at the end of the $18^{\text {th }}$ century and had already lost their specific meaning of 'movement towards a goal' and 'prediction' (see Bybee \& alii 1994 : 266ff).

Riemer in his 1779 Saamaka dictionary, inspired by Schumann's 1778 dictionary, writes that $s a$ is a possible future marker in Saamaka but is not the most common one which is tann/tan go. This is the exact replica of the de go construction in Early Sranan. He adds that $s a$ has a modal meaning of 'obligation', which is also sometimes found in the other texts (van Dyk for example):

(vD) da bassia takki mi za go na mastra
the overseer talk I FUT go LOC master
fo locke koekeroe worke.
to look cook work

'The overseer said I should come to you to work in the kitchen.'

(Arends \& Perl $1995: 185$ )

There does not appear to be a model for the progressive future (de go) construction attested in Early Sranan in the substrate languages and Dutch, and the 'be going to' construction in English emerged only at the end of the 17th century. The most likely scenario then seems to be internal development. Bybee $\&$ alii (1994) show that when a future emerges in a language, it generally first emerges as an 'immediate future' (I'm on my way doing it right now), and later turns into a simple future (mi go ...). This suggests that $d e$ and go were first juxtaposed in a progressive construction (de go $V$ ) and then reduced to a simple form go $V$.

However, the question is why Early Sranan, which already had the future marker sa, developed the 'de go $V /$ go $V$ ' construction. Two hypotheses suggest themselves. According to hypothesis One, the de go V/go $V$ construction emerged because $s a$ was acquiring modal meanings. Initially, the $s a V$ future construction, which was modeled on the substrate construction (Winford \& Migge to appear) and had been in existence since creole formation, was used to express a predictive future by itself and uncertain future when combined with the adverb zomtem. However, later, during the later $18^{\text {th }}$ century, $s a$ started to take on mainly modal meanings. To 
fill this gap left behind by the semantic change/extension of $\mathrm{sa}$, the de go $\mathrm{V} / \mathrm{go} \mathrm{V}$ construction developed at the end of the $18^{\text {th }}$. Initially, it was a 'movement towards a goal' construction combined with the progressive form and expressed immediate future. It then reduced to a simple future construction $(g o+V)$ and extended its meaning to conveying predictive future.

Although it is well-attested in the literature that future markers can gradually become epistemic modality markers (see Bybee \& alii 1994; Heine \& Kuteva 2002), this analysis does not explain how $s a$ spread to all the meanings in the 'potential' category such as root possibility and physical and mental ability in the Maroon Creoles (Migge to appear). According to Bybee \& alii (1994 : 205ss), the attested developmental path goes from ability to root possibility and then epistemic possibility, and not the other way round. Moreover, it does not help us to explain why $s a$ disappeared from several potential categories in Sranan, but was kept in the maroon Creoles.

Hypothesis Two maintains that the sa $V$ and the de/tan go $V$ future constructions each belong to different Creole varieties. The variation in the Early texts is then due to contact between these two varieties. Since the beginning, at least two varieties of Creole existed: Nengre Tongo and Bakra Tongo. The former was spoken by Europeans and much influenced by Dutch while the latter was the language of the plantation slaves. According to Schumann and Riemer, the Nengre Tongo variety employed the tann go (Saamaka) and de go - go (Sranan Tongo) construction to mark future and $s a$ had a modal value. In Bakra Tongo, however, $s a$ was the main future marker. The variation found in the future domain between sa / de go and go in some of the early texts, which most likely mainly reflect Bakra Tongo usage, then occurred because the Nengre Tongo forms (de go, go) were beginning to spread to Bakra Tongo. The ' $g o V$ ' construction - the Nengre variants - finally generalizes (at the expenses of the Bakra Tongo construction involving $s a$ as a future marker) probably due to the overwhelming numerical strength of the slave population. At the time, the number of slaves was growing rapidly clearly outnumbering the existing slaves - in 1783 the black-to-white ratio in Suriname was 24:1 (Arends 1995: 260). Following that period, go phonologically reduced to $o$ and came to show a high degree of cliticization in the contemporary Creoles (see Goury 2003). Unlike the maroon Creoles, Sranan Tongo retained the two future constructions (Winford 2000b). The de go $V$ construction conveys an aspectual value of 'prospective' while the $o V$ 
construction conveys a temporal value of future time reference and prediction. $S a$ is retained as a modality marker though with only partially similar values in Sranan and the Maroon Creoles (Migge to appear, Winford 2000a).

\section{Conclusion}

Our sociohistorical analysis showed that several linguistic inputs played a role in both the initial emergence and development of the Creoles of Suriname. L2 varieties of English and to a lesser extent L2 varieties of Portuguese, and varieties of Kikongo and Gbe were crucially involved in the initial formation of the early Creole varieties. Once the Creole varieties had emerged, they were influenced by other West African languages, Carib languages and by Dutch because of changes in the social makeup of the setting. Our comparative linguistic analysis largely supports these findings. First, the overall makeup of the Creole TMA system resembles that of Gbe in many respects. Second, some categories that have been in existence since the beginning such as the Perfective are either clearly modeled on Gbe counterparts or the emergence of categories and the elements that express them were at least in part triggered by substrate models (progressive). Third, other areas that also date from the initial formation of the Creole varieties were largely based on English models (Past marker), Dutch models (Future $s a$ in Bakra Tongo), or Portuguese models (Completive marker kaba).

Comparison of modern and early textual data also revealed that some aspects such as the use of the progressive marker to express habitual and generic meanings only emerged later, possibly due to a process of semantic extension. Other categories such as the predictive future that, based on an analysis of just synchronic data, appeared to be substrate calques were found to have emerged due to internal development.

Based on a correlation of synchronic and diachronic linguistic data and available sociohistorical information, the variation apparent in the early written sources (and differences between the modern and diachronic data) in the area of future tense marking, was found not to be due to gradual language-internal change. Instead, it appears to have emerged due to contact between different varieties of Creole, namely Nengre Tongo and Bakra Tongo, that had been in existence since the beginning. Towards the end of the 18th century the latter variety spoken by the 
Europeans and their associates was increasingly merging with the dominant variety, Nengre Tongo, giving rise to linguistic variation and change.

Our investigation then challenges views that see creolization or Creole formation as a separate, unitary and abrupt process of language creation (cf. Thomason \& Kaufman 1988) and supports views that conceptualize Creole formation as a gradual and multi-layered process (Arends 1993, Bruyn 1995) involving processes of language change that also operate in other so-called 'normal' contact settings (Thomason \& Kaufman 1988). Our discussion suggests that the present-day TMA system emerged in several stages involving first, 'interference through shift' speakers of African language reinterpreted strings and elements from L2 English according to L1 models - and retention of superstrate models. Second, other elements, categories and functions emerged later either as a result of processes of gradual language-internal change (and contact) affecting elements that had previously emerged due to interference through shift or retention, or due to processes of contact between partially different Creole varieties that coexisted in the same context.

\section{References}

Arends, Jacques (1999) The origin of the Portuguese element in Surinam Creoles.. In Huber M. \& Parkvall M. Eds. Spreading the Word. The issue of diffusion among the Atlantic Creoles. (pp 195-208) University of Westminster Press, London.

Arends, Jacques (1995) Demographic factors in the formation of Sranan. The early stages of creolization, ed. By Jacques Arends, 233-285. Amsterdam: John Benjamins.

Arends, Jacques (1993) Towards a gradualist model of creolization. Atlantic meets Pacific, ed. by Francis Byrne and John Holm, 371-380. Amsterdam: John Benjamins.

Arends, Jacques. (1986). Genesis and development of the equative copula in Sranan. Substrata versus universals in creole genesis, ed. by P. Muysken \& N. Smith, 103128. Amsterdam: John Benjamins. 
Arends, Jacques \& Matthias Perl (1995) Early Surinamese Creole texts : A collection of 18th-century Sranan and Saramaccan documents. Frankfurt: Vervuert; Madrid: Iberoamericana.

Bickerton, Derek (1984) The language bioprogram hypothesis. Behavioral and Brain Sciences 7.173-221.

Bruyn, Adrienne (1995) Grammaticalization in creoles: The development of determiners and relative clauses in Sranan. Studies in language and language use, 21. Amsterdam: IFOTT.

Bybee, Joan, Perkins, R. \& Pagliuca, W. (1994) The evolution of grammar : Tense, aspect, and modality in the languages of the world. Chicago : University of Chicago Press.

Carlin, Eithne \& Boven, Karin (2002) The native population. Migrations and identities. In Carlin Eithne \& Arends Jacques Eds., The Atlas of the Languages of Suriname. Pp. 11-45. KITLV Press, Leiden.

Chaudenson, Robert (1992) Des îles des hommes, des langues. Paris: L'Harmattan.

Comrie, Bernard (1976) Aspect: An introduction to the study of verbal aspect and related problems. Cambridge: Cambridge University Press.

DeGraff, M. (ed.) (1999) Creolization, language change, and language acquisition: An epilogue. Language Creation and Language Change: Creolization, Diachrony and Development, ed. by Michel DeGraff, 473-543. Cambridge, MA: The MIT Press.

de Kleine Christa (2002) Surinamese Dutch. In Carlin Eithne \& Arends Jacques Eds., The Atlas of the Languages of Suriname. Pp. 209-230. KITLV Press, Leiden.

Desclés, Jean Pierre (1989) State, event, process and topology. General linguistics 29.159-200. 
Detges, Ulrich (2000) Two types of restructuring in French creoles: A cognitive approach to the genesis of tense markers. Degrees of restructuring in creole languages, ed. by Ingrid Neumann-Holzschuh and Edgar Schneider, 135-162. Amsterdam: John Benjamins.

Dupuis, Francis (2005) Enjeux territoriaux dans le Haut Maroni. In Ethnies 31-32. Guyane : le renouveau amérindien. Pp. 62-71.

Essegbey, James (2004) The potential morpheme in Ewe. Unpublished ms.

Fabb, Nigel (1992) Reduplication and object movement in Ewe and Fon. Journal of African languages and linguistics 13.1-40.

Fattier Dominique, 2003. Grammaticalisation en créole haïtien : morceaux choisis. Online publication $:$ http://www.creolica.net/article.php3?id article=19.

Focke, H.C (1855) Neger-Engels Nederlands Woordenboek. Online publication : http://www.sil.org/americas/suriname/Focke/National/FockeNLDict.html

Goodman, M. (1987) The portuguese element in the American creoles. Pidgin and creole languages, ed. by Glenn Gilbert, 361-405. Honolulu: University of Hawaii Press.

Goury, Laurence (2003) Le ndyuka. Une langue créole du Surinam et de Guyane française. L'Harmattan, Paris.

Heine, Berndt \& Kuteva, Tania (2002) World lexicon of grammaticalization. Cambridge University Press, Cambridge.

Hoogbergen, Wim (1983). Marronage en marrons, 1760-1863. De niet-gepacificeerde marrons van Suriname. Suriname, de schele onafhankelijkheid, ed. by G. Willemsen, 75-110. Amsterdam: de Arbeiderspers. 
Huttar, Georges and Frank Velanti 1997. Ndyuka-Trio Pidgin. Contact languages: A wider perspective, ed. by Sarah G. Thomason, 99-124. Amsterdam: John Benjamins.

Jondoh, E. (1980). Some aspects of the predicate phrase in Gengbe. Indiana University, Bloomington, ms.

Kramp, Andre (1983) Early Creole Lexicography : A Study of C.L Schumann's Manuscript Dictionnary of Sranan. Thèse de Doctorat. Université de Leyden.

Kriegel, Sybille, Michaelis, Suzanne \& Pfänder, Stephan (2004) Modalité et grammaticalisation : le cas des creoles français. In Kriegel, Sybille (dir).

Grammaticalisation et réanalyse. Approche de la variation créole et française. Pp. 165-191. CNRS Editions, Paris.

Lefebvre, Claire (1996) The tense, mood and aspect system of Haitian Creole and the problem of transmission of grammar in creole genesis. Journal of Pidgin and Creole Languages 11.231-313.

Migge, Bettina (2000) The origin of property items in the Surinamese Plantation Creole. Language Change and Language Contact in Pidgins and Creoles, ed. by John H. McWhorter, 201-234. Amsterdam: John Benjamins.

Migge, Bettina (2002) The origin of the copulas $(d / n) a$ and $d e$ in the Eastern Maroon Creole. Diachronica 19.83-136.

Migge, Bettina (to appear) Tracing the origin of modality in the creoles of Suriname." In Structure and variation in contact languages, ed. by A. Deumert and S. Durrleman-Tame. Amsterdam: John Benjamins.

Rens, L. (1953). The historical and social background of Surinam's Negro English. Amsterdam, Netherlands: North-Holland.

Schuchardt, Hugo (1914) Die Sprache der Saramakkaneger in Surinam. Johannes Müller, Amsterdam. 
Siegel, Jeff. (1999) Transfer constraints and substrate influence in Melanesian Pidgin. Journal of Pidgin and Creole Languages 14:1-44.

Thomason, Sarah G. and Terrence Kaufman (1988) Language contact, creolization, and genetic linguistics. Berkeley, CA: University of California Press.

van den Berg, Margot (2000) "Mi no sal tron tongo". Early Sranan in court records. 1667-1767. Mémoire sous la direction de J.Arends. Université de Nijmegen.

van den Berg, Margot (2001) “'Mingo, joù no man’; Oud-Sranan in verhoren en verslagen van rechtszaken", OSO 20:241-253.

van den Berg, Margot. \& Arends, Jacques (2004) The Saramaka Peace Treaty in Sranan : an edition of the 1762 text (including a copy of the original text). Creolica, www.creolica.net.

Van der Putte, Rénie (2005) Surinaamse ‘weglopers’ van de jaren 1767-1802. Oso 24.276-288.

Winford, Donald (1997). Property items and predication in Sranan. Journal of Pidgin and Creole Languages 12.237-301.

Winford, Donald (2000a) Irrealis in Sranan: Mood and modality in a radical creole. Journal of Pidgin and Creole Languages 15.63-125.

Winford, Donald (2000b) Tense and aspect in Sranan and the Creole Prototype. Language change and language contact in Pidgins and Creole, ed. by John $\mathrm{H}$. McWhorter, 383-442. Amsterdam: John Benjamins.

Winford \& Migge (to appear) Substrate influence on the emergence of the TMA systems of the Surinamese Creoles. Journal of Pidgin and Creole Languages. 